\title{
Impact Of Statutory Retirement Age On Youth Unemployment In Kwara State, Nigeria
}

\author{
ISIAKA Sulu Babaita \\ Department of Business Administration, \\ University of Ilorin, Ilorin, Nigeria \\ WOLI-JIMOH, Ibrahim Ayodeji \\ Kwara State Ministry of Justice, Ilorin. Nigeria
}

\begin{abstract}
Youth unemployment is a pressing problem in both the advanced and developing countries of this world of which Nigeria is not an exception. More worrisome is the few research works linking Statutory Retirement Age (SRA) to youth unemployment. However, to add to the growing concern on the subject matter, the current study empirically examines the impact of statutory retirement age on youth unemployment rate in Kwara State. The study used simple random sampling technique to select a sample size of 390 civil servants from Kwara State Civil Service Commission (KWCSC). It also interviewed a focus group of graduates undergoing the One-Year program of the Kwara Bridge Empowerment Scheme (KWABES). Data obtained were presented using both descriptive and inferential statistics of simple percentage. Regression Analytical tool was used to test the hypotheses formulated for the study. The results indicate that the variability changes in the rate of youth unemployment could be accounted for by approximately $84.3 \%$ of increase in statutory retirement age. Also, the variability changes in the level of job creation opportunities could be accounted for by approximately $63.2 \%$ of factors related to statutory retirement age This established that increase in statutory retirement age have effect of increasing youth unemployment and the level of job creation depends on factors that are related to SRA. Base on this conclusions, it was recommended that the KWCSC should focus on strict implementation of SRA policies and Programmes and by this, the state government can deal decisively with the problems of youth unemployment through the Statutory Retirement Age.
\end{abstract}

Keywords: Statutory, Retirement, Youth, unemployment, Kwara, Nigeria

\section{BACKGROUND TO THE STUDY}

Youth unemployment is a pressing problem in both the advanced and developing countries of this world. According to World Bank data (2014) the unemployment rate for youth is 15.7\% aged15-24 ranged from 3.7\% in Thailand to 59.0\% in Greece (Labour Market Statistic, 2014).However, of the 65 countries for which data are available, 59 had a male youth unemployment rate above $10 \%$. Data from the Organisations of Economic Cooperation and Development (OECD) for 2010 show that almost 13\% of youth aged 15-24were not in education, employment, or training, with the increase in the Baltic countries, Ireland, and Spain. Policy makers who advocate increases in the retirement age are accused of worsening the chances of young people getting jobs (Labour Market Statistic, 2014). African Youth Charter refers to youths in age range of 15 to 35 (United Nations Educational, Scientific \& Cultural 
Organisation, 2014). This age range represents over $60 \%$ of the African continent's total population. Although more than $50 \%$ of the youth population in Africa is illiterate. Those that have some qualifications often exhibit skills irrelevant to current demand in the labour market. With the prevailing growth in educational and skill requirements, millions of youth are either unemployed or sometimes underemployed (African Economic Outlook, 2015). South Africa has the highest in Africa with a figure of over $50 \%$. Nigeria has a youth unemployment rate of over $13 \%$ (Tighisti, 2014) Statutory retirement age which is also known as an enforced or mandatory retirement age is the set age at which persons who hold certain jobs or offices are required by industry, custom or law to leave their employment by retirement. Typically, statutory retirement age is justified by the argument that certain occupations are either too dangerous (military) or mentally and physically requiring high skill levels (airline pilots). Most rely on the notion that workers' productivity decline significantly after certain age, particularly at 60years in the case of Nigeria and that statutory retirement age is the employer's way to avoid huge cost on unproductive workers. The statutory retirement age is often somewhat arbitrary and not based upon an actual physical evaluation of an individual employee's productivity. In countries like United States of America and Canada, statutory retirement age is unlawful except in certain industries.

There is a growing concern that the total monthly package of a worker who has attained the mandatory age of 60 years can sufficiently create youth employment opportunities for a minimum of four fresh graduates (Kwara State Bureau of Statistics, 2014). The argument is, whether such money saved on recurrent expenditure will be used by government to create job opportunities for the youth or not. It has been argued that elongating the statutory retirement age will prevent career advancement of some civil servants that are supposed to fill the vacancies created by the exit of retiring civil servants(United Nations, World Youth Report, 2012). It is also argued that the elongation could further compound the youth unemployment rate which could have been ameliorated, if the statutory retirement age was properly managed.

While in some developed countries, increasing the statutory retirement age is done to solve the problem of pension. In other developed countries, it is a crime to do so (Allen, 2012).Although the labour unions of countries that increased their statutory retirement age had vehemently opposed such policies leading to protests and strikes which happened specifically in France.

In developing countries such as Nigeria, increasing statutory retirement age is perceived as a temporary source of income, the stream of which a retiree may not receive, if retired. While this may be true of the civil servants in Ministries, Departments and Agencies (MDA), the same cannot be said of the judicial, health and academic institutions. Another issue raised by the statutory retirement age is that, government can create more jobs having known the expected number of civil servants due for retirement at a nearer future date. Although, this practice is political, but also seen to possibly mitigate youth unemployment rate (Kwara State Civil Service Commission, Bulletin 2011).

The abolition of the mandatory 35 years in service while retaining only the 60 years statutory retirement age by the Edo state government (Ibileke, 2014) threw up the challenge of reducing unemployment rate of older people rather than those of the youth in the face of a rising youth unemployment rate in Nigeria.

This research work was informed by the evolving issues raised above and hence the need to tackle the rising rate of youth unemployment through a thorough review of statutory retirement age (SRA) policies and programmes. 


\section{Research Questions}

This research work intends to answer the following questions;

i. what is the effect of statutory retirement age on youth unemployment?

ii. what is the effect of statutory retirement age on job creation opportunities?

\section{Objectives of the Study}

The main objective of the study is to examine the impact of the statutory retirement age on youth unemployment in Kwara state. And the specific objective is to examine the effect of statutory retirement age on job creation opportunities.

\section{Test of Hypotheses}

The following hypotheses shall be tested in the course of the study;

$\mathrm{H}_{01:}$ Statutory retirement age has no significant impact on youth unemployment.

$\mathrm{H}_{02:}$ Statutory retirement age has no significant effect on job creation.

\section{Scope of the study}

The primary focus of this research as implied by the general objective is to find out the impact of statutory retirement age on youth unemployment rate in Kwara state. The study was carried out in Kwara State, Nigeria and Kwara State civil service was chosen because the state is prided as having the least unemployment rate in Nigeria ((Boldwin and Adedayo, 2014).

\section{REVIEW OF RELATED LITERATURE:}

\section{Conceptual Review of Statutory Retirement Age and Unemployment}

Retirement is defined as the act of retiring or the state of being retired (Atchley,2000). That is, to withdraw oneself from business public life or to remove oneself from active service. Thus, the process of retirement involves the transition of people's experience, when they move from a job role performed for pay, to the role of a retired person. Here, it is referred, to a retired person who had previously worked for either a private organisation or public service for pay. However, after a stated period, such person exits the paid job either to permanently not be involved in any work activity or to withdraw only from a paid job.

Normal retirement age is the age at which a retirement plan allows for full benefits (Fisher 2011). In private pension plans, the date is frequently calculated as a combination of age and years of employment. But for the nation's largest and most ubiquitous Pension plan that is Social Security, the right to full benefits are determined largely by age. Social Security's normal retirement age varies by date of birth. It can range from people born in 1937 or before who get full benefits at age 65 to those born in 1960 or later who have to wait until they turn 67 (United States Bureau of Statistics, 2012).

Statutory Retirement Age also known as Mandatory or Enforced Retirement Age has been in practice in both the private and public service worldwide (Osuala, 2005). It is a major stage in adult development and it marks the split from the middle years to the old age (Osuala, 2005). At the age of 65 years, our mental and physical abilities diminishes; however, it becomes rationale to relieve an employee of some strenuous and excruciating duties that may have a telling effect on and consequently threaten his health. This, therefore, results to normal retirement age of 65 years (Osuala, 2005). The statutory retirement age therefore is a set age backed by the law of a country. 
In some developed and economically buoyant countries there is no statutory retirement age or even illegal to have a statutory retirement age. Some other countries have their statutory retirement age set at same age for both men and women or different for both sexes. In Nigeria, due to the economic crunch and high rate of unemployment among other factors the Statutory Retirement Age (SRA) was put at 55years or after 25years of service by General Ibrahim Babangida's regime (Federal Bureau of Statistics, 2008). And until recently when the Federal Government of Nigeria pegged it to 60 years or 35 years of service or whichever is attained first(Atchley2000).

Unemployment occurs when a person who is actively searching for job is unable to find work. Unemployment is often used as a measure of the health of the economy. The most frequently cited measure of unemployment is the unemployment rate. This is the number of unemployed persons divided by the number of people in the labour force. Many different variations of the unemployment rate exist with different definitions concerning who is an "unemployed person" and who is in the "labour force' (United States Bureau of Labour Statistics, 2014).

\section{THEORETICAL FRAMEWORK}

\section{Theory of Retirement}

The Life-Cycle Theory of Saving and Retirement. The model was built by Bloom, Canning and Moore (2007). This theory reveals that people may engage in precautionary saving to guard against income shocks, and they may also save to provide bequests (personal properties such as money, stock, bonds, or jewellery) (Skinner 2007). In the interest of simplicity, the researcher assumed that the life cycle has no period of schooling. Schooling will affect the productivity of workers, their health and longevity, and their utility of leisure (Heckman 2007) complicating a retirement. The results give the optimal retirement and savings behaviour of fully rational agents under complete capital markets. In practice, imperfect capital markets (particularly annuity markets), lack of foresight about the need to save for retirement, and time inconsistency in preferences will distort private decisions, generating a role for social security systems (Hubbard\& Judd 2007; Feldstein,2007 and Laibson et al. 2007). Mandatory retirement may prevent individuals from responding optimally to longer life spans through longer working lives. Although few social security systems have mandatory retirement, a substantial body of evidence indicates that retirement in industrial countries clusters around specific ages that depend on retirement incentives inherent in the national social security system (Gruber \& Wise 2004). The conclusion of the model demonstrates two major long-term influences on the optimal age at retirement and on savings behaviour.

Modern Retirement Theory (MRT). The theory was propounded by Jason and Grubbs (2010). The model offers customized solutions for each individual retiree. It is centred on proprietary process which is a retirement plan that is secured, stable, and sustainable for the retiree's lifetime. It is about issue of longevity and conditions within longevity. The model is premised on six assumptions namely; absolute goal, individualized and client centric, outlook ambiguity, secure-stablesustainable(3S), 'Retirement Sheet' Assets and Funding Priority. The major focus here is the 3S, where the first $\mathrm{S}$ (secure) refers to income level which must offer a guarantee of some sort or a back stop of protection. The second S (stable) refers to income which must not fluctuate widely and the third S (sustainable) refers to income level which must be for life times.

\section{Theoretical review of Unemployment THEORY OF UNEMPLOYMENT.}

Classical Theory of Unemployment as analysed by Pigou (2000) and Solow (2014), argues that the labour market consists of demand and supply of labour. Demand for labour is a derived demand, obtained from the declining portion of the marginal product of labour. The demand 
curve is a negative function of real wage in that if wages increase the quantity demand for labour will decline and the opposite is correct. The supply of labour is derived from worker's choice whether to spend part of time working or not working (leisure). Supply of hours worked is a positive function of the real wage, because if the real wage rises, workers supply more hours of work. In equilibrium, demand and supply of labour are intersected at a clearing point that determines the equilibrium real wage rate and full employment (Sweezy,2000).

\section{EMPIRICAL REVIEW}

IZA World of Labour (2014) submitted that the average effective retirement age is the mean age at which older workers withdraws from the labour force to retire and it is lower than the official retirement age. The official retirement age for men in Germany was 65 and the effective retirement age was 62, according to the (OECD, 2014). The research findings show that most wealthy countries have a lower effective retirement age dating back to the 1970s, however such trend has been halted. IZA World of Labour concluded that the basic public policy dilemma is the conflict between the use of early retirement as an instrument for alleviating unemployment among younger workers and the longer term financial viability of pension systems in ageing societies.

Stefan and Zweimüller (2011) in their work examined how an increase in the minimum retirement age affects the labour market behaviour of older workers. The results from the study suggest that the policy change reduced retirement by 19 percentage points among affected men and by 25 percentage points among affected women. The decline in retirement was accompanied by a sizeable increase in employment of 7 percentage points among men and 10 percentage points among women, but had also important spill-over effects into the unemployment insurance program (Staubil, 2013). Specifically, the unemployment rate increased by 10 percentage points among men and 11 percentage points among women. In contrast, the policy change had only a small impact on the share of individuals claiming disability or partial retirement benefits.

\section{METHODOLOGY}

The research was conducted to examine the impact of Statutory Retirement Age on youth unemployment in Kwara State.

\section{Research Design}

Descriptive research design method is adopted for the conduct of this study, because the data that were used were qualitative in nature. This study used collection of primary opinions on statutory retirement age and its relative impact on youth unemployment, which is achieved through administration of questionnaires.

\section{Population for the Study}

The population of this study includes all the civil servants and all the unemployed graduates residing in Kwarastate totalling 17,560. However, since it is not practically possible to collect data from the entire population and all the unemployed graduates residing in Kwara State, it became imperative for the study adopt a hypothetical sample in line with the views of Attwell\& Rule (1991), that a hypothetical sample may be used for an unknown population. Hypothetical sample positively select elements that exhibit desired features that are the focus of the research's study. 


\section{Measurements:}

\section{Hypotheses}

$\mathrm{H}_{1}$ : There is no significant relationship between statutory retirement age and youth

Unemployment in Kwara state.

$\mathrm{H}_{2:}$ There is no significant relationship between statutory retirement age and job creation opportunities in Kwara state.

Hypothesis One:

$\mathrm{H}_{1}$ There is no significant relationship between statutory retirement age and youth

Unemployment in Kwara state

Table 4.1 Variables Entered/Removed ${ }^{b}$

\begin{tabular}{|l|l|l|l|}
\hline Model & Variables Entered & Variables Removed & Method \\
\hline 1 & Statutory retirement age $^{\mathrm{a}}$ & & Enter \\
\hline
\end{tabular}

Source: Author's computation, 2015

a. All requested variables entered.

b. Dependent Variable: Youth Unemployment

Table 4.1 Posited that Statutory retirement age and youth unemployment were variables entered respectively to test whether or not Statutory retirement age has impact on youth unemployment.

Table 4.2 Model Summary

\begin{tabular}{|l|l|l|l|l|}
\hline Model & $\mathrm{R}$ & R Square & Adjusted R Square & $\begin{array}{l}\text { Std. Error of the } \\
\text { Estimate }\end{array}$ \\
\hline 1 & $.918^{\mathrm{a}}$ & .843 & .843 & .543 \\
\hline
\end{tabular}

Source: Author's computation, 2015

a. Predictors: (Constant), Statutory retirement age

The $\mathrm{R}$-square value as depicted in table 4.2 is $0.843(84.3 \%)$ and the adjusted R-Square is $0.843(84.3 \%)$. This indicates that the variability changes in the amount of youth unemployment could be accounted for by approximately $84.3 \%$ of issues related to statutory retirement age. This established that statutory retirement age has impact on youth unemployment.

Table 4.3 ANOVA ${ }^{b}$

\begin{tabular}{|rl|r|r|r|r|r|}
\hline Model & & Sum of Squares & df & Mean Square & F & \multicolumn{1}{c|}{ Sig. } \\
\hline 1 & Regression & 544.658 & 1 & 544.658 & $1.849 \mathrm{E} 3$ & $.000^{\mathrm{a}}$ \\
& Residual & 101.345 & 344 & .295 & & \\
& Total & 646.003 & 345 & & & \\
& & & & & \\
\hline
\end{tabular}

Source: Author's computation, 2015

a. Predictors: (Constant), Statutory retirement age

b. Dependent Variable: Youth Unemployment

Table 4.1 indicates that the calculated P-value is 0.000 (positive) which is less than alpha value of 0.05 , therefore, the Null hypothesis which states that statutory retirement age has no impact 
on youth unemployment is thereby rejected, while the Alternative hypothesis which establishes that statutory retirement age has impact on youth unemployment is adopted. At $95 \%$ level of confidence, the calculated ' $F$ ' value of the model which is 1.849 which depicts that the statistical significance of the analysis is valid.

Table 4.4 Coefficients ${ }^{2}$

\begin{tabular}{|c|c|c|c|c|c|}
\hline \multirow[b]{2}{*}{ Model } & \multicolumn{2}{|c|}{$\begin{array}{c}\text { Unstandardized } \\
\text { Coefficients }\end{array}$} & \multirow{2}{*}{\begin{tabular}{|c|}
$\begin{array}{c}\text { Standardized } \\
\text { Coefficients }\end{array}$ \\
Beta
\end{tabular}} & \multirow[b]{2}{*}{$\mathrm{T}$} & \multirow[b]{2}{*}{ Sig. } \\
\hline & B & Std. Error & & & \\
\hline (Constant) & .059 & .071 & & .829 & .408 \\
\hline Statutory retirement age & .990 & .023 & .918 & 42.997 & .000 \\
\hline
\end{tabular}

Source: Author's computation, 2015

a. Dependent Variable: Youth Unemployment

Table 4.4 reveals that the intercept and slope (i.e. B) of the model are 0.059 and 0.990 respectively. This could be written in model form as YOUN $=0.059+990_{\text {SRA }}+$ E. Where YOUN $=$ "Youth Unemployment", SRA = Statutory Retirement Age, and E= Error term.

\section{Hypothesis Two:}

$\mathrm{H}_{2:}$ Statutory retirement age has no effect on job creation opportunities.

The second objective is to examine the impact of statutory retirement age on job creation.

Table 4.5 ANOVA ${ }^{b}$

\begin{tabular}{|ll|r|r|r|r|r|}
\hline Model & & Sum of Squares & \multicolumn{1}{c|}{ df } & Mean Square & \multicolumn{1}{c|}{ F } & \multicolumn{1}{c|}{ Sig. } \\
\hline 1 & Regression & 594.024 & 1 & 594.024 & $4.694 \mathrm{E} 3$ & $.000^{\mathrm{a}}$ \\
& Residual & 43.536 & 344 & .127 & & \\
& Total & 637.561 & 345 & & & \\
\hline
\end{tabular}

Source: Author's computation, 2015

a. Predictors: (Constant), The current statutory retirement age is good for Kwara State Civil Service.

b. Dependent Variable: major objective of government agenda is job creation

Table 4.5 shows that the calculated P-value is 0.000 (positive) which is less than alpha value of 0.05 , therefore, the Null hypothesis which states that statutory retirement age has no effect on job creation opportunities is rejected, while the Alternative hypothesis which establishes that statutory retirement age has effect on job creation opportunities is adopted. At 95\% level of confidence, the calculated ' $F$ ' value of the model which is 4.69 is greater than the ' $F$ ' tabulated value of the model which is 3.42. This indicates that the statistical significance of the analysis is valid 
Table 4.6 Coefficients ${ }^{a}$

\begin{tabular}{|c|c|c|c|c|c|c|}
\hline \multirow[b]{2}{*}{ Model } & & \multicolumn{2}{|c|}{$\begin{array}{c}\text { Unstandardized } \\
\text { Coefficients } \\
\end{array}$} & \multirow{2}{*}{$\begin{array}{c}\text { Standardized } \\
\text { Coefficients }\end{array}$} & \multirow[b]{2}{*}{$\mathrm{t}$} & \multirow[b]{2}{*}{ Sig. } \\
\hline & & B & Std. Error & & & \\
\hline 1 & (Constant) & .049 & .044 & & 1.118 & .264 \\
\hline & $\begin{array}{l}\text { The current statutory } \\
\text { retirement age is good for }\end{array}$ & 10025 & 015 & & & \\
\hline & $\begin{array}{lll}\text { Kwara } & \text { State } & \text { Civil } \\
\text { Service. } & & \end{array}$ & 1.025 & | & 903 & 00.210 & .000 \\
\hline
\end{tabular}

Source: Author's computation, 2015

a. Dependent Variable: major objective of government agenda is job creation

Table 4.6 reveals the coefficient of the regression model. The intercept and slope (i.e B) as reflected in the table are 0.0 .49 and 1.025 respectively. This could be written in model form as $\mathrm{JCOP}=0.049+1.025 \mathrm{SRA}+\mathrm{E}$. Where JCOP='Job Creation Opportunities",SRA =Statutory Retirement Age and E= Error term".

Table 4.7 Model Summary

\begin{tabular}{|c|c|c|c|c|}
\hline Model & $\mathrm{R}$ & R Square & Adjusted R Square & $\begin{array}{l}\text { Std. Error of the } \\
\text { Estimate }\end{array}$ \\
\hline 1 & $.965^{\mathrm{a}}$ & .632 & .632 & .356 \\
\hline
\end{tabular}

Source: Author's computation, 2015

a. Predictors: (Constant), The current statutory retirement age is good for Kwara State Civil Service.

The $\mathrm{R}$-square value as depicted in table 4.7 is $0.632(63.2 \%)$ and the adjusted R-Square is $0.632(63.2 \%)$. This indicates that the variability changes in the level of job creation opportunities could be accounted for by approximately $63.2 \%$ of factors related to statutory retirement age. This posited that statutory retirement age has significant effect on job creation opportunities.

\section{DISCUSSIONS OF FINDINGS}

The findings established that the currently adopted statutory retirement age is not good for Kwara state civil service because it does not allow for more than proportionate employment of youths.The $\mathrm{R}$-square value as depicted in Table 4.1 is $0.843(84.3 \%)$ and the adjusted RSquare is $0.843(84.3 \%)$. This indicates that the variability changes in the number of youth unemployment could be accounted for by approximately $84.3 \%$ of issues related to statutory retirement age. This established that statutory retirement age has significant impact on youth unemployment.

Findings also revealed that statutory retirement age has significant effect on job creation opportunities. Government can create job if it can determined the number of civil servants that are due for retirement. The $\mathrm{R}$-square value as depicted in Table 4.5 is $0.632(63.2 \%)$ and the adjusted R-Square is $0.632(63.2 \%)$. This indicates that the variability changes in the level of job creation opportunities could be accounted for by approximately $63.2 \%$ of factors related to statutory retirement age. 


\section{CONCLUSION}

The specific objective of this research work is to examine the impact of the statutory retirement age on youth unemployment. The current policy of 35 years in service or 60 years of age or whichever is earlier has contributed hugely to unemployment problems in Kwarastate. The second objective is to examine the effect of statutory retirement age on job creation opportunities. Statutory retirement age can be used to create job opportunities.

\section{RECOMMENDATIONS}

Federal and State governments should review downward the current policy of SRA and implement strictly with a view to reducing the growing incident of youth unemployment. This can be achieved through the acquisition of software packages such as bambooHR, clearcompany, icims, Ascentis, KRONOS, Sage HRMS and others which will keep records of all civil servants in the employment of Kwara State Government. These software are users friendly and with adequate and continuous training of KWCSC personnel, fraudulent and material alteration will be difficult to alter. This will arrest the criminal alterations of material records common with civil servants.

Government should also establish a data bank where all unemployed youth in the state can be registered. Public enlightenment should be embarked upon to encourage unemployed persons to register for job opportunities with the government. This will give the government a fair knowledge, if not actual figure of youth unemployed.

\section{References}

Agbaegbu, T. (2011, January 31). Why Unemployment is High in Nigeria. Newswatch Magazine.P. 18-20.

Akaeze, A. (2011, January 31). Their Dreams, Their Frustrations. For millions of Nigeria

Youths, Paid employment remains a pipe dream many years after graduation. Newswatch Magazine. P. 17-21.

Asaju, K. et al, (2014). The Efficacy of Fiscal Policy in promoting Economic Growth and Poverty Reduction in Nigeria.Research in World Economy, 5(1): 33-44.

Atchley, R. C. (1985).The Social Forces in Later Life. (4th ed.). Belmont, C.A: Wardsworth.Publishing.

Attwell, P.\& Rule, J. B. (2014): Survey and Other Methodologies Applied to IT impact Research: Experience from a competitive study of Business Computing. A journal

OfManagement Information System Special Section. 10(2), 75-105. Retrieved on from http://dl.acm.org/citation.cfm

Awosusi, O. \&Jegede, A. O. (2010).Sustenance of Food Production and Food Security in Ekiti State, Nigeria. International Journal on Food and Agriculture Research. 7(1), 14-21.

Bloom, D. \&David C, (2007).A Theory of Retirement.NBER: Working Paper. No. W13630. Retrieved from

Bolarin, V. W. (1998).Counselling for Retirement.The Counsellor, 16(1). Retrieved from http:/eujournal.org/index.php/esj

Bosworth, B. \& Gary, B. (2010). Recessions, Wealth Destruction and the Timing of retirement:Centre For Retirement Research, Boston College, Working Paper. (Revised October, 2011). Retrieved from http://Crr.bc.edu/.../2010

Bukoye, R. O. (2005). Problems Associated with Retirement Among Retiring Civil Servants.

The Counsellor, 21(6), 207-217.

David, B.\&Michael, M. (2004).The Effect of Improvements in Health and Longevity on Optimal Retirement and Saving.National Bureau of Economic Research, Working Paper.DOI-10.3386/w. 10919. 
David F. R. (2011). The Rate of Changes of Wages Against Unemployment. Retrieved from http://anticap.wordpress.com

Ekah, T.(1987).Making Retirement Comfortable for Army Personnel. Ibadan, Tiger Publishers. Retrieved from http://eujournal.org/index.php/esj/article

Feldstein, M. S. (1985).The Optimal Level of Social Security Benefits.Quarterly Journal of Economics, 10(2), 303320 .

Gruber, J \& David,A. W. (1999): Social Security and Retirement around the World.University of Chicago Press. 99(1), 1-35. Retrieval from http://www.nber.org/chapters/c7247

Hackman, J \& Oldham, G. R. (1976).Motivation through the Design of Work: Test of a theory: Organisation behaviour and Human Performance, 16(2), 250-279.

Hubbard, G. \& Judd, K. L. (1976). Social Security and Individual Welfare: Precautionary saving, Borrowing Constraints and the Payroll Tax. The American Economic Review, 77(4), 630-646.

International Labour Organisation (2012). Global employment trends for youth 2012. Retrieved from http://www.ilo.org/wcmsp5/groups/public/...dgreports/---/wcms-180976

IZA World of Labour (2014): Global Expert Discuss Aid, Youth unemployment and Minimum Wages.Weiner Eichharist. Retrieved from http://www.newsroom.iza.org

Jackman, R.\& Roper, S. (1987).Structural Unemployment.Oxford Bulletin ofEconomics and Statistics, 49 (1), 9-36.

Janson, B \& Grubbs, R. M. (2010).Modern Retirement Theory.Journal of Human Resource, 40(2), 354-372.

Kerkoff, A. C. (1996).Family Patterns and Morale in Retirement in Ida Simpson and John.The Journal of Gerontology,60(5), 219-231. Retrieved from http://roa.sagepub.com/content/19/3/251.citation.

Kolade-Otitoju, B. (2009, June 29). President UmaruYar'Adua's Mid-term report card is a mix of broken promises and outright failures.The News.P.7-9.

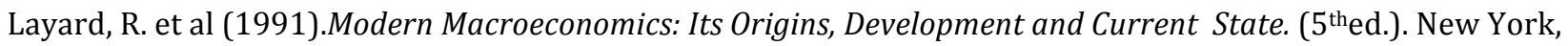
NY: York Publishing.

Lewis, W. A. (2003). The Theory of Economic Growth: (30th ed.). 453 pgs. London, Eng: World Bank.

Manion, V.U.(1976). Pre-retirement Counselling: The Personal and Guidance Journal, 55 (3), 119-121.

Mouhammed, A. H. (2011). Veblen' Important Theories of Unemployment and Public Policies: Journal of Institutional and Theoretical Economics, 155(4), 594-609.

Ndifon, X. (2009, December 15).The problem of Unemployment in Nigeria.Fountain Magazine.P. 15-17.

Obadan, M. \&Odusola, A. F. (1999). Savings Investment and Growth Connections in Nigeria: Empirical Evidence and Policy Implication. A journal of NCEMA Policy Analysis Series. 1(2), 20-26. Retrieved from http://www.cbn.gov.ng/OUT.

Ogidan, R.J. (2005). Across Ethnic Study of Attitudes Adjustment Needs and Support Systems of Retired Nigeria Federal Civil Servants.Unpublished Ph.D. ThesisOndo State University, Ado-Ekiti, Nigeria. Retrieved: http://eujournal.org/index.php/esj/

Ogunmade, O. (2013, June 19).\$600bn Stolen by Nigerian Elite since independence. ThisDay Newspaper. P. 2.

Okigbo, P. N. (2010), Theoretical and Methodological Issues Relating to Unemployment and Underemployment in Nigeria. Journal of Nigerian Economic Society, 5(2), 13-17.

Omoresemi, A. A. (1987).Retirement Challenges and Sustainable Development in Nigeria. An European Journal of Business and Management, 6(39), 94-98.

Osuala, E. C. (1985). Retirement Counselling is Necessary. Nigerian Statement, P. 8-17.

Piguo, A. C. (2007). The Theory of Unemployment. (5thed.).London: Macmillan: 314pgs.

Samuel, A. (2011). The Democratic Challenges in Nigeria and The steps toward achieving the Vision 20:20:20. Kubani Journal of Arts and Social Sciences, 1(1): 14-22. 
Scholte J. (2011). NHS Pension Scheme: Incorporating The NHS Compensation for Premature Retirement Scheme Accounts 2010-2011. London. The Station. Retrieved from http://www.nhsbsa.nhs.uk ID- 244171013620.

Skinner, B. (1988).Unemployment Insurance and Precautionary Savings. NBER Working Paper 3-95. 5252. Retrieved from http://www.sciencedirect.com/science/article/B6

Solow, R.\& Ian, M. M. (1981).Wages and Employment in a Segmented Labour Market. Oxford Journals of Economics, $100(4), 1115-1141$.

Staubli, S. \&Zweimuller J. (2011). "Does Raising the Retirement age Increase Employment of Older Workers?. University of Zurich, 20(1), 1-46 Retrieved from http://www.idea.repec.org

Staubli, S. etal(2013).Extended Unemployment and Early Retirement: Program Complementarity and Program Substitution.Journal of Research in Labour Economics, 39(1), 219-258.

Sweezy, P. (1934). Professor Piguo'sTheory of Unemployment. Journal of Economic History, 7(2), 800-811.

Tighisti, A. (2014, July 11). Africa's High Youth Unemployment: is population to blame?. The Guardian Newspaper.P. 2. Retrieved from www.theguardian.com/.../africa- youth 